Research Article

\title{
Association between gestational age and persistent pulmonary hypertension of the newborn (PPHN) severity in preterm babies at Sidoarjo Regional Hospital
}

\author{
Aisyah Faadhilah ${ }^{1 *}$, M. Perdana Airlangga ${ }^{2}$, Nurma Yuliyanasari $^{3}$, Gina Noor Djalilah ${ }^{4}$ \\ 1) Medical Student, Faculty of Medicine Universitas Muhammadiyah Surabaya \\ 2,3,4) Faculty of Medicine, Universitas Muhammadiyah Surabaya
}

\section{A R T I C L E I N F O}

A R T I C L E I N F O

\begin{tabular}{ll}
\hline Submitted & : September 2020 \\
Accepted & : December 2020 \\
Published & : January 2021 \\
\hline
\end{tabular}

\section{Keywords:}

Persistent pulmonary hypertension of the newborn, PPHN, Preterm Babies

\section{*Correspondence:}

aisyahhelmadevithalib@gmail. com

\section{ABSTRACT}

Persistent pulmonary hypertension of the newborn (PPHN) is a condition that occurs due to increased resistance to blood vessels in the lungs that occur persistently after the baby is born. This can be attributed to congenital heart disease such as right-to-left shunts through foramen ovale (PFO) or patent ductus arteriosus (PDA) due to an error transition fetal blood circulation to the neonate. Although PPHN is always associated with births in post-term babies, PPHN cases are often found in preterm babies. Chances of babies born with PPHN are quite large, at $1.9 \%$ per 1000 live births. PPHN can be fatal, causing mortality rates ranging from 4 to $33 \%$. The incidence of preterm births in Indonesia is estimated at 7-14\%, around 459,200 - 900,000 babies per year. This study aimed to prove the relationship between premature babies and persistent pulmonary hypertension of the newborn (pphn) in Sidoarjo Regional Hospital and to know the characteristics and analyze these variables. This research used crossed sectional studied design; the population was all preterm babies in the NICU at Sidoarjo regional hospital. All samples are from medical records in January-December 2018. There is a significant difference between preterm babies and PPHN $(p<0.05)$; besides, the results from Spearman's correlation analysis obtained a correlation coefficient $(\rho)=0.485$. In the cross-tabulation analysis, the result of the proportion with the highest correlation was Late Preterm babies with severe PPHN of $46.7 \%$. It can be concluded that there is a relationship between premature babies and PPHN in Sidoarjo regional hospital. 


\section{INTRODUCTION}

Persistent pulmonary hypertension of the newborn (PPHN) is a condition that occurs due to increased resistance to blood vessels in the lungs that occur continuously or persistently after the baby is born. This can be associated with congenital heart diseases such as the right to left shunt through the foramen ovale (PFO) or patent ductus arteriosus (PDA) due to an error in the transition of fetal blood circulation to the neonate (Park \& Chung, 2017). This condition is caused by pulmonary artery pressure or pulmonary vein with a mean pulmonary artery pressure (PAP) $>25 \mathrm{mmHg}$ at rest or $>30 \mathrm{mmHg}$ during activity (Prawira \& Yanuarso, 2016). The PPHN classification includes 3 categories, namely mild PPHN (PASP 36-45 mmHg), moderate PPHN (PASP 45-60 $\mathrm{mmHg}$ ), and severe PPHN (PASP > 60 mmHg) (de Boode et al., 2018).

Although PPHN is always associated with births in post-term babies, PPHN cases are often found in babies with preterm conditions (Park \& Chung, 2017). Also, according to research conducted by Steurer et al. (2017), this study explains that late preterm infants have the highest risk of developing PPHN when compared to higher age groups (Steurer et al., 2017). Babies with preterm birth are births that occur at 20-37 weeks of gestation (Grzesiak et al., 2018). Preterm birth can be classified into three categories, namely, very preterm infants (28- $<33$ weeks), moderately preterm infants (33- $<35$ weeks), and late preterm infants (35- $<37$ weeks) (Harju et al., 2014).

The cases of babies born with PPHN are quite large, at $1.9 \%$ per 1000 live births (Park \& Chung, 2017). PPHN can be fatal, causing the mortality rate to range from 4 to $33 \%$ (EL-Khuffash et al., 2018). The incidence of preterm birth in Indonesia is estimated at $7-14 \%$, which is around 459,200 - 900,000 babies per year (Utami, Ernawati, \& Irwanti, 2016).

Premature babies have a 2.5 times greater risk of suffering from a patent ductus arteriosus (PDA) and ventricular septal defect (VSD). PDA and VSD are directly related to the persistent incidence of pulmonary hypertension of the newborn (PPHN) (Ontoseno, 2018). Preterm birth has a significant risk because it is related to the baby's underripe organs, such as the lungs, brain, gastrointestinal tract (Grzesiak et al., 2018). The mechanism of PPHN in babies born prematurely is caused by vascular immaturity in the lungs and imperfections in its development (de Boode et al., 2018). PPHN was diagnosed by the clinical manifestation and confirmed by a neonatologist who performed echocardiography (NPE) (Ontoseno, 2018).

In Indonesia, there are rarely journals that examine persistent pulmonary hypertension of the newborn or neonates (PPHN), mainly when associated with the condition of babies born prematurely. This study aims to prove the relationship between premature babies and persistent pulmonary hypertension of the newborn (PPHN) in Sidoarjo regional hospital and to see the characteristics and analyze these variables.

\section{METHOD}

This study used an observational analytic research method with a cross-sectional study design and used a consecutive sampling technique. The independent variable is the age at birth of premature babies, and the dependent variable is Persistent pulmonary hypertension of the newborn (PPHN). This study's population was all infant patients in the Sidoarjo regional hospital's NICU room from January to December 2018. The samples in the study were obtained based on the inclusion and exclusion criteria as follows: 
The inclusion criteria of this study were: (1) patients with preterm birth, (2) patient was admitted to the NICU, (3) patient was diagnosed with PPHN and confirmed by echocardiography, (4) patient did not have meconium aspiration syndrome (MAS), (5) patient did not have a congenital diaphragmatic hernia. The exclusion criteria of this study were: (1) patients with non-preterm birth, (2) patient was not admitted to the NICU, (3) patient was not diagnosed with PPHN (4) patient did has meconium aspiration syndrome (MAS), (5) patient did has a congenital diaphragmatic hernia.

This study used medical records from the NICU of Sidoarjo regional Hospital to get information about echocardiograms, doctors' diagnoses, and patient clinical status. The data was analyzed using the Spearman's Rho Test and Cross Tabulation SPSS version 25. This research has been approved and certified legally by the Health Research Ethics Committee section of the Sidoarjo regional Hospital with ethical letter number 002 / KET-KEPK / XII-2019.

\section{RESULTS}

In this study, preterm infants were classified into three categories, namely, very preterm infants (28- $<33$ weeks), moderately preterm infants (33- $<35$ weeks), and late preterm infants (35- < 37 weeks). The PPHN classification includes three categories, namely mild PPHN (PASP 36-45 mmHg), moderate PPHN (PASP 45-60 mmHg), and severe PPHN (PASP $>60$ $\mathrm{mmHg}$ ) (de Boode et al., 2018). The number of premature babies diagnosed with PPHN was 30 babies. Of the 30 babies, 18 babies were late preterm, 10 were moderately preterm and 2 were very preterm.

\section{Characteristics of Premature Babies with PPHN at Sidoarjo Regional Hospital}

From Table 1, it can be seen that the characteristics of premature babies with PPHN include Pulmonary Hypertension (PHT), preterm category, diagnosis, baby weight, and baby's sex. In the Pulmonary Hypertension (PHT) category, the sample affected by PPHN (a total of 30 babies) was the most severe PHT with 18 babies, then 8 babies mild PHT and the least was moderate PHT with 4 babies. The most preterm categories of samples affected by PPHN (a total of 30 babies) were late preterm category with 18 babies, then 10 moderately preterm babies and the least was very preterm with only 2 babies.

From Table 1, the diagnoses of the sample affected by PPHN (a total of 30 babies) were the highest number of Severe PPHN + PDA + ASD as many as 10 babies, and the second most were the Severe PPHN + ASD as many as 7 babies. The body weight of babies from the sample affected by PPHN (a total of 30 babies) was mostly Low Birth Weight $(<2500 \mathrm{gr})$ as many as 20 babies, then normal weight was 9 babies and the least was very low birth weight $(<1500$ gr $)$ with the number only 1 baby. And it can be seen that the sex of the babies from the sample affected by PPHN (a total of 30 babies) was mostly male, as many as 21 babies, while the lowest was female with 9 babies. 
Table 1. Characteristics of Premature Babies with PPHN at the Sidoarjo regional Hospital in 2018

\begin{tabular}{lll}
\hline Babies Characteristics & N & $\mathbf{\%}$ \\
\hline & & \\
1. Pulmonary Hypertension (PHT) & & \\
Severe & $18 / 30$ & 60 \\
Moderate & $4 / 30$ & 13 \\
Mild & $8 / 30$ & 27 \\
\hline 2. Prematur Category & & \\
Late Preterm & $18 / 30$ & 60 \\
Moderately Preterm & $10 / 30$ & 33 \\
Very Preterm & $2 / 30$ & 7 \\
\hline
\end{tabular}

3. Diagnose

Mild PPHN

Mild PPHN + ASD

Mild PPHN + PDA

Mild PPHN + PDA + ASD

Mod. PPHN + ASD

Mod. PPHN + PDA + ASD

Severe PPHN + PDA + ASD

Severe PPHN + ASD

Severe PPHN + PFO

$\begin{array}{ll}3 / 30 & 10 \\ 3 / 30 & 10 \\ 1 / 30 & 3 \\ 1 / 30 & 3 \\ 2 / 30 & 7 \\ 2 / 30 & 7 \\ 10 / 30 & 34 \\ 7 / 30 & 23 \\ 1 / 30 & 3\end{array}$

4. Baby Weight

$\begin{array}{lll}\text { LBW } & 20 / 30 & 67 \\ \text { VLBW } & 1 / 30 & 3 \\ \text { Normal } & 9 / 30 & 30\end{array}$

5. Sex

Male

Female

$\begin{array}{ll}21 / 30 & 70 \\ 9 / 30 & 30\end{array}$




\section{Characteristics of Premature Mother Babies} with PPHN at Sidoarjo Regional Hospital

From Table 2, it can be seen that the characteristics of premature infants with PPHN include maternal age, gravidity and parity, and type of labor. Most of the range of the mother was 20-30 years. The highest number of samples affected by PPHN (a total of 30 babies) was multigravida, while the lowest was the primigravida. The type of delivery was mostly by Caesarean section (SC).

\section{Relationship between Premature Babies and PPHN}

The total number of premature babies at Sidoarjo regional Hospital with PPHN diagnoses was 30 babies. Of the 30 babies, 18 babies were late preterm, ten were moderately preterm, and two were very preterm.

After conducting a descriptive analysis, an analysis was carried out using the Spearman's test to determine whether there was a relationship between premature babies and persistent pulmonary hypertension of the newborn (PPHN) at Sidoarjo regional Hospital.

Based on Table 3, it is obtained p value $<0.05$, which indicates that the correlation between premature babies and PPHN is significant. Spearman's rho correlation value of 0.485 indicates a positive correlation with strong correlation strength.

To see which category of premature babies is the most significant for PPHN can be done by calculating the Cross tabulation. The results of the calculation are as follows

From the results in Table 4, the largest proportion is Late Preterm, with severe PPHN with a total of $46.7 \%$, so that Late Preterm is the most significant preterm category for severe PPHN.

Table 2. Characteristics of mothers in premature babies with PPHN at the Sidoarjo Regional Hospital in 2018

\begin{tabular}{|c|c|c|}
\hline $\begin{array}{l}\text { Characteristic of } \\
\text { Mothers }\end{array}$ & $\mathbf{N}$ & $\%$ \\
\hline \multicolumn{3}{|l|}{ 1. Age } \\
\hline$<20$ Year & $0 / 30$ & 0 \\
\hline $20-30$ Year & $14 / 30$ & 47 \\
\hline $31-35$ Year & $10 / 30$ & 33 \\
\hline$\geq 36$ & $6 / 30$ & 20 \\
\hline \multicolumn{3}{|l|}{$\begin{array}{l}\text { 2. Gravidity dan } \\
\text { Parity }\end{array}$} \\
\hline & $22 / 30$ & 73 \\
\hline $\begin{array}{l}\text { Multigravida } \\
\text { Primigravida }\end{array}$ & $8 / 30$ & 27 \\
\hline \multicolumn{3}{|l|}{ 3. Type of Labor } \\
\hline & $24 / 30$ & 80 \\
\hline $\begin{array}{l}\text { Caesar (SC) } \\
\text { Normal }\end{array}$ & $6 / 30$ & 20 \\
\hline
\end{tabular}




\section{QANUN MEDIKA Vol 5 No 1 JANUARY 2021}

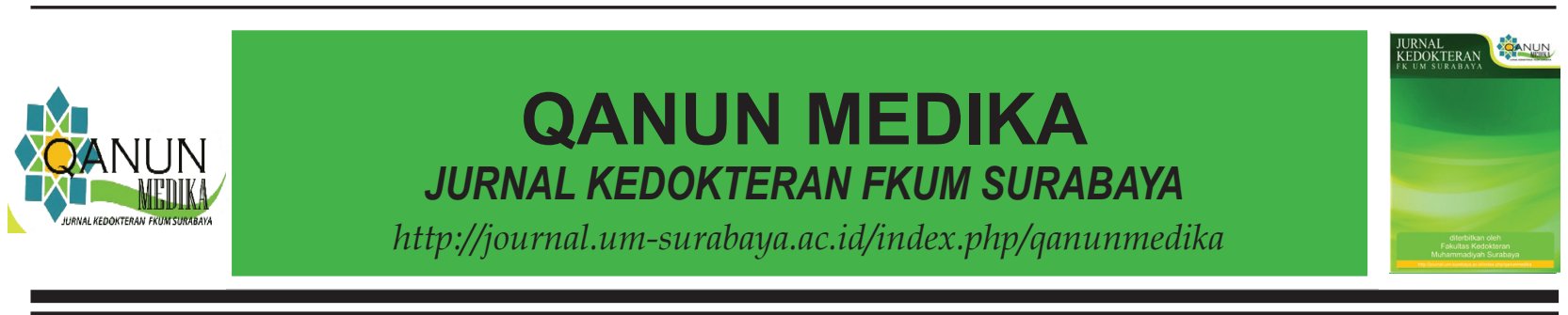

Table 3. Spearman's Rho Test Results of Relationship between Premature Babies and PPHN Incidence

\section{PRETERM}

\begin{tabular}{ll}
\hline PPHN & $\mathrm{r}=0,485$ \\
$\mathrm{p}<0,05$ \\
$\mathrm{n}=30$
\end{tabular}

Table 4. Calculation Results of Cross Tabulation

\begin{tabular}{|c|c|c|c|c|c|c|}
\hline & & & & PRETERM & & \\
\hline \multirow{9}{*}{ PPHN } & \multirow{4}{*}{ MILD } & & $\begin{array}{c}\text { VERY } \\
\text { PRETERM }\end{array}$ & $\begin{array}{c}\text { MODERATELY } \\
\text { PRETERM }\end{array}$ & $\begin{array}{c}\text { LATE } \\
\text { PRETERM }\end{array}$ & TOTAL \\
\hline & & Count & 1 & 5 & 2 & 8 \\
\hline & & & $3.3 \%$ & $16.7 \%$ & $6.7 \%$ & $26.7 \%$ \\
\hline & & Total & & & & \\
\hline & \multirow[t]{3}{*}{ MODERATE } & Count & 1 & 1 & 2 & \\
\hline & & $\%$ & $3.3 \%$ & $3.3 \%$ & $6.7 \%$ & $13.3 \%$ \\
\hline & & Total & & & & \\
\hline & \multirow[t]{2}{*}{ SEVERE } & Count & 0 & 4 & 14 & 18 \\
\hline & & $\%$ & $0.0 \%$ & $13.3 \%$ & $46.7 \%$ & $60.0 \%$ \\
\hline \multirow{4}{*}{ Total } & & Total & \multirow{4}{*}{$\begin{array}{r}2 \\
6.7 \%\end{array}$} & \multirow{4}{*}{$\begin{array}{r}10 \\
33.3 \%\end{array}$} & \multirow{4}{*}{$\begin{array}{r}18 \\
60.0 \%\end{array}$} & \multirow{4}{*}{$\begin{array}{r}30 \\
100.0 \%\end{array}$} \\
\hline & & Count & & & & \\
\hline & & & & & & \\
\hline & & Total & & & & \\
\hline
\end{tabular}

\section{DISCUSSION}

Premature birth or preterm is birth that occurs at 20-37 weeks of gestation, counted from the first day of the last period (Harju et al., 2014). Whereas the newborn's persistent pulmonary hypertension (PPHN) is a condition that occurs due to increased resistance to blood vessels in thelungs that occur continuously or persistently after the baby is born (Park \& Chung, 2017). Based on the results of the analysis using Spearman's rho test method in Table 4, it was found that the level of significance was $p$ $<0.05$. Therefore, the conclusion is that there is a relationship between preterm babies and PPHN. And the results obtained correlation coefficient $(\rho)=0.485$, which states that there is a strong enough relationship between the two variables, namely premature babies with the incidence of PPHN. In the cross-tabulation analysis, it was found that the proportion with the highest relationship was late preterm babies with severe PPHN of $46.7 \%$.

According to research conducted by Steurer et al. (2017), this study explains that late preterm babies have the highest risk of developing PPHN when compared to higher age groups (Steurer et al., 2017). This can be explained because in babies with preterm birth, the pulmonary blood vessels' smooth muscle is not fully developed as in term babies, and there is thinning of these blood vessels. Oxygen pressure (O2) decreases, making blood vessel tone increase, even though the tone increase will quickly be compensated for a few moments after birth (Ontoseno, 2018). This is as explained in the study of Binalole et al. (2014) that the majority of $>80 \%$ of preterm births are late preterm births (Binalole et al., 2014). So this causes the highest data of $46.7 \%$ 
in the late preterm category of the total preterm categories.

Although most literature states that PPHN occurs in infants with post-term and term births, this study was conducted to prove the relationship between preterm infants and the incidence of PPHN. Premature babies have a 2.5 times greater risk of suffering from a patent ductus arteriosus (PDA) and ventricular septal defect (VSD), which are directly related to the incidence of persistent pulmonary hypertension of the newborn (PPHN) (Ontoseno, 2018).

The pathophysiology of PPHN events related to congenital heart disease can be caused by vascular remodeling and increased resistance to pulmonary vessels. The vasoconstriction of pulmonary arteries due to the imbalanced production of endogenous vasodilators and vasoconstrictor's production. The endogenous vasodilators such asnitric oxideand prostacyclin, while the endogenous vasoconstrictors' such as endothelin-1 and serotonin (Ivy et al., 2013). Changes in the expression of vasoactive mediators, consisting of endothelin-1, prostacyclin, and nitric oxide, resulting in vasoconstriction. In contrast, endothelial expression in vascular and fibroblast growth factors triggers vascular remodeling resulting in hypertrophy and smooth muscle proliferation, and increased matrix deposition intracellular. It affects increasing pulmonary vascular resistance (Adatia, Kothari, \& Feinstein, 2010). In the study of D'Alto and Mahadevan (2012) it was explained that congenital heart disease (CHD) with left to right shunts results in pulmonary arterial hypertension due to increased blood flow to the lungs (D'Alto \& Mahadevan, 2012). Based on the analysis, severe PPHN is the highest number of PPHN incidents with a total of $46,7 \%$. It can be concluded that the number of CHD and types of CHD suffered by infants, the heavier the PPHN suffered by these babies (Sargowo, 2017).
In a study conducted by Nakanishi et al. (2018) it was found that there was a relationship between premature babies and the incidence of PPHN, especially in Extremely Preterm babies or $<28$ weeks because the subjects in the study were only Extremely Preterm (Nakanishi, Suenaga, Uchiyama, \& Kusuda, 2018). This study using a cohort study so that further analysis can be carried out in the long term. This is the weakness of this study when compared to a cohort study. However, reflecting on research (Steurer et al., 2017), the same results were obtained in this study, PPHN is more dominant in late preterm babies. The strength of this study compared to other studies is that a specific analysis is carried out, looking for the relationship between premature babies which is divided into 3 grades, namely very preterm babies $(28-<33$ weeks), moderately preterm babies $(33-<35$ weeks) and late preterm (35- $<37$ weeks), compared to the incidence of PPHN which is also divided into 3 grading which includes mild PPHN (PASP 36-45 $\mathrm{mmHg}$ ), moderate PPHN (PASP 45$60 \mathrm{mmHg}$ ), and severe PPHN (PASP $>60$ $\mathrm{mmHg}$ ). The PPHN classification is based on PASP pressure. the heavier the PPHN grade, the more severe the disease. The prognosis will get worse. However, the prognosis is based not only on the PPHN grade but also on the patient's congenital heart disease. The more congenital heart disease suffered, the worse the patient's prognosis will be.

This study's drawbacks are the limited number of samples with a relatively short sample period and only covering one year. Even so, research on the relationship between preterm infants and PPHN has never been conducted in Indonesia before. However, it is hoped that this research can be carried out on a wider population in the future, with larger sample size, a longer period, and the research design uses the cohort method. So that more specific data results will be obtained and accurate. 


\section{CONCLUSION}

The analysis results concluded that there is a relationship between premature babies and PPHN at the Sidoarjo regional Hospital. The highest relationship was Late Preterm babies with severe PPHN. Based on the data, the essential characteristics that affect the relationship between premature babies and PPHN at Sidoarjo regional Hospital are maternal age, gravidity and parity, type of labor, congenital heart disease (CHD), and baby weight.

\section{REFERENCES}

Adatia, I., Kothari, S. S., \& Feinstein, J. A. (2010). Pulmonary hypertension associated with congenital heart disease: Pulmonary vascular disease: The global perspective. Chest, 137(6 SUPPL.), 52S-61S.

Binalole et al. (2014). Kandidat Skripsi Fakultas Kedokteran Universitas Sam Ratulangi Manado 2 Email. Jurnal E-Clinic (ECl), 2(3), 2-5.

D’Alto, M., \& Mahadevan, V. S. (2012). Pulmonary arterial hypertension associated with congenital heart disease. European Respiratory Review, 21(126), 328-337.

de Boode, W. P., Singh, Y., Molnar, Z., Schubert, U., Savoia, M., Sehgal, A., ... El-Khuffash, A. (2018). Application of Neonatologist Performed Echocardiography in the assessment and management of persistent pulmonary hypertension of the newborn. Pediatric Research, 84(1), 68-77.

EL-Khuffash, A., McNamara, P. J., Breatnach, C., Bussmann, N., Smith, A., Feeney, O., ... Dempsey, E. (2018). The use of milrinone in neonates with persistent pulmonary hypertension of the newborn a randomised controlled trial pilot study (MINT 1): study protocol and review of literature. Maternal Health, Neonatology and Perinatology, 4(1), 1-12.

Grzesiak, M., Gaj, Z., Kocyłowski, R., Suliburska, J., Oszukowski, P., Horzelski, W., ... Banach, M. (2018). Oxidative stress in women treated with atosiban for impending preterm birth. Oxidative Medicine and Cellular Longevity, 2018, $1-8$.

Harju, M., Keski-Nisula, L., Georgiadis, L., Räisänen, S., Gissler, M., \& Heinonen, S. (2014). The burden of childhood asthma and late preterm and early term births. Journal of Pediatrics, 164(2).

Ivy, D. D., Abman, S. H., Barst, R. J., Berger, R. M. F., Bonnet, D., Fleming, T. R., ... Beghetti, M. (2013). Pediatric pulmonary hypertension. Journal of the American College of Cardiology, 62(25 SUPPL.).

Nakanishi, H., Suenaga, H., Uchiyama, A., \& Kusuda, S. (2018). Persistent pulmonary hypertension of the newborn in extremely preterm infants: A Japanese cohort study. Archives of Disease in Childhood: Fetal and Neonatal Edition, 103(6), F554F561.

Ontoseno, T. (2018). Penyakit Jantung Pada Anak Jilid 1 Edisi 1. Surabaya: Sagung Seto.

Park, B. Y., \& Chung, S. H. (2017). Treprostinil for persistent pulmonary hypertension of the newborn, with early onset sepsis in preterm infant: 2 Case reports. Medicine (United States), 96(26), 1-5.

Prawira, Y., \& Yanuarso, P. B. (2016). Sildenafil Sebagai Pilihan Terapi Hipertensi Pulmonal Pascabedah Jantung Koreksi Penyakit Jantung Bawaan pada Anak. Sari Pediatri, 11(6), 456. 


\section{QANUN MEDIKA}

Sargowo, D. (2017). Gagal Jantung Kiri Dan Hipertensi Pulmonal. Journal of Islamic Medicine, 1(1), 9.

Steurer, M. A., Jelliffe-Pawlowski, L. L., Baer, R. J., Partridge, J. C., Rogers, E. E., \& Keller, R. L. (2017). Persistent pulmonary hypertension of the newborn in late preterm and term infants in California. Pediatrics, 139(1).
Utami, E. E., Ernawati, S., \& Irwanti, W. (2016). Hubungan Frekuensi Kunjungan Antenatal Care (ANC) dengan Kejadian Prematur. Jurnal Ners Dan Kebidanan Indonesia, 2(1), 27. 